УДК 327.7: 061.1(477)

DOI: $10.24144 / 2218-5348.2019 .1-2(19-20) .18-28$

Тодоров Ігор,

доктор історичних наук, професор, професор кафедри міжнародних студій та суспільних комунікаиій

Тодорова Наталія, кандидат філологічних наук, дочент, доцент кафедри полікультурної освіти та перекладу ДВНЗ «Ужсгородський національний університет»

\title{
ІМПЛЕМЕНТАЦІЯ УГОДИ ПРО АСОЦАЦІЮ МІЖ УКРАЇНОЮ ТА ЄС: БЕЗПЕКОВИЙ ВИМІР
}

У статті висвітлено імплементацію частини Угоди про асоціацію між Україною та ЄС у площині питань безпеки. Окреслено зміст та сутність другого розділу Угоди про асоиіацію «Політичний діалог та реформи, політична асоџіація, співробітництво та конвергениія у сфері зовнішньої та безпекової політики», визначено кількісні $i$ якісні характеристики реалізації положень Угоди щзодо безпекових питань з літа 2014p. до жовтня 2019 р. за допомогою системи моніторингу виконання Угоди про асоиіацію ("Пульс угоди").

Ключові слова: Угода про асочіачію, Свропейський Союз, Пульс угоди, російська агресія в Украӥну, запобігання конфліктам, врегулювання криз.

The article covers the processes to implement a part of the EU-Ukraine Association Agreement on security issues. The content and substance of the second section of the Association Agreement, "Political Dialogue and Reforms, Political Association, Cooperation and Convergence in Foreign and Security Policy", were outlined. Political dialogue has been proven to be gaining momentum for the gradual convergence of foreign and security issues in order to bring Ukraine closer to the European Security Area. Russia's annexation of Crimea and its aggression in the Donbas have dramatically changed the direction of foreign and security policy cooperation. Ukraine and the EU cooperated in the so-called "Normandy format". The EU supports these efforts and continues to exert pressure on Russia by imposing personal and sectoral sanctions. It supports the role played by the Organization for Security and Co-operation in Europe (OSCE) in overseeing the implementation of the Minsk Protocols through the OSCE Special Monitoring Mission and the OSCE Mission of observers, whose task is to monitor borders and observance of ceasefire agreements. 
In 2017, the "Pulse of the Agreement" was introduced, reflecting the current progress of implementing the measures planned within each year and the overall progress of implementing the Association Agreement. The monitoring system, which can be openly accessed since November 2019, analyses the quantitative and qualitative indicators of adapting the EU legislation towards "National Dialogue, National Security and Defence". It is concluded that the greatest progress is being made in this area (Ukraine has fulfilled $84 \%$ of its commitments). At the same time, a dialogue is needed on strengthening the EU sanctions regime against the Russian Federation and establishing regular meetings of Heads of General Staff of Ukraine, Visehrad Group countries and the Baltic States to exchange experience and best practices.

Keywords: Association Agreement, European Union, Pulse of Agreement, Russian aggression in Ukraine, conflict prevention, crisis management.

Актуальність дослідження обумовлена конституційним закріпленням європейської інтеграції України та новим етапом імплементації Угоди про асоціацію між Україною та ЄС. Понад п'ять років тому була підписана Угода про асоціацію між Україною та Європейським Союзом, і йде третій рік 3 набуття нею чинності. Текст же Угоди був готовий до підписання і парафований міністром економіки ще в 2012 році. Отже, треба враховувати, що змістовно багато в чому Угода застаріла і не враховує сучасних реалій,головним чином обумовлених російською агресією проти України. Втім, іншого універсального міжнародно-правового документа, що регламентує відносини України з Свропейським Союзом, немає і не буде до його повної імплементації. Окремі аспекти проблеми цього дослідження були предметом наукових розвідок вітчизняних учених, зокрема таких дослідників як І.Артьомов [1], В.Геєць [2], О.Дем'янчук [3], О.Левченко [4], В.Муравйов [5], О.Носова [6], О.Пошедін [7] та інших.Втім, поглиблення російської агресії проти України та сучасне посилення російських впливів на $Є С$ потребує подальших досліджень у цьому напрямі.

Метою статті $\epsilon$ висвітлення імплементації частини Угоди про асоціацію між Україною та $\mathrm{CC}$ стосовно питань безпеки. Реалізація визначеної мети відбувалася шляхом вирішення таких завдань: (а) окреслення змісту та сутності другого розділу Угоди про асоціацію «Політичний діалог та реформи, політична асоціація, співробітництво та конвергенція у сфері зовнішньої та безпекової політики», (б) визначення кількісних і якісних характеристик імплементації положень Угоди щодо безпекових питань 3 літа 2014p. до жовтня 2019 p.

Переговори про укладення нової посиленої угоди на заміну Угоди про партнерство та співробітництво розпочато 5 березня 2007 р. У 2008 р. майбутня угода отримала назву - про асоціацію. Протягом 2007-2011 pp. проведено 21 раунд переговорів щодо підготовки Угоди про асоиіацію між 
Україною та ЄС. 18 лютого 2008 р. розпочалися переговори стосовно укладення Угоди про зону вільної торгівлі (ЗВТ) між СС та Україною (після завершення процесу вступу України до СОТ). Загалом було проведено 18 раундів переговорів з Україною стосовно ЗВТ. Про завершення переговорів щодо Угоди про асоціацію було заявлено 19 грудня 2011 р. Угода про асоціацію (УА) була парафована і готова до підписання вже 19 липня 2012 р. Після повалення правління В.Януковича Угоду нарешті було підписано: політичну частину - 21 березня 2014 р., у цілому - 27 червня 2014 р. Європейський парламент ратифікував Угоду синхронно з Верховною Радою України 16 вересня 2014 р. Після ратифікації всіма країнами-членами СС Угода набрала чинності 1 вересня 2017 р. Кабінет Міністрів 25 жовтня 2017 р. затвердив план заходів щодо реалізації Угоди про асоціацію України 3 Євросоюзом. Цей документ передбачав 2 тис. заходів і 5 тис. завдань. Профільний урядовий комітет щоквартально заслуховує звіти про виконання плану. $Є$ сподівання, що реалізація Угоди про асоціацію приведе до того, що питання членства України в СС перейде у політичну площину.

Другий розділ угоди «Політичний діалог та реформи, політична асоиіація, співробітництво та конвергениія у сфері зовнішньої та безпекової політики» безпосередньо торкається питань безпеки. У статті 4 Цілі політичного діалогу йдеться про те, що в усіх сферах, що становлять взаємний інтерес, має розвиватися та зміцнюватися політичний діалог задля поступової конвергенції із зовнішніх питань та питань безпеки для глибшого залучення України до Європейської зони безпеки. Цілями політичного діалогу визначено: (а) поглиблення політичної асоціації та зміцнення політико-безпекової конвергенції та ефективності;(б) сприяння міжнародній стабільності та безпеці на основі ефективної багатосторонності; (в) посилення співробітництва та діалогу 3 питань міжнародної безпеки та антикризового управління, зокрема 3 метою реагування на глобальні й регіональні виклики та основні загрози;(г) пришвидшення зорієнтованого на результат та практичного співробітництва для досягнення миру, безпеки й стабільності на Європейському континенті; (г) зміцнення поваги до демократичних принципів, верховенства права та доброго врядування, прав людини та основоположних свобод, у тому числі прав осіб, які належать до національних меншин, недискримінації осіб, які належать до меншин, i поваги до різноманітності, а також внесок у консолідацію внутрішніх політичних реформ; (д) розвиток діалогу та поглиблення співробітництва у сфері безпеки та оборони; (е) сприяння принципам незалежності, суверенітету, територіальної цілісності й непорушності кордонів.

У сьомій статті Угоди $\epsilon$ принципове положення про те, що співробітництво грунтуватиметься на спільних цінностях і спільних інтересах та спрямовуватиметься на посилення політичної конвергенції й ефективності, сприяння спільному політичному плануванню. Україна, СС та держави-члени 
підтвердили свою відданість принципам поваги до незалежності, суверенітету, територіальної цілісності та непорушності кордонів, як це визначено у Статуті ООН та Гельсінському заключному акті Наради 3 безпеки та співробітництва в Європі 1975 року, а також поширюють ці принципи у двосторонніх та багатосторонніх відносинах.

Україна та Європейське оборонне агентство встановлюють тісні контакти для обговорення питань, пов'язаних з удосконаленням військових спроможностей, зокрема питань технічного характеру.Україна та ЄС підтверджують важливість спільного управління міграційними потоками між їхніми територіями та надалі розвиватимуть всеохоплюючий діалог щодо всіх питань у сфері міграції, зокрема легальної та нелегальної міграції, незаконного переправлення осіб через державний кордон та торгівлі людьми, а також включення проблемних питань у сфері міграції до національних стратегій економічного та соціального розвитку регіонів, звідки походять мігранти. Такий діалог грунтується на основоположних принципах солідарності, взаємної довіри, спільної відповідальності та партнерства.Згідно 3 відповідним законодавством $€ C$ та чинним національним законодавством, співробітництво має зосереджуватись на: (а) подоланні причин виникнення міграції, активно використовуючи можливості співробітництва у цій сфері з третіми країнами та в рамках міжнародних форумів; (б) спільному запровадженні ефективної та превентивної політики щодо боротьби 3 нелегальною міграцією, незаконним переправленням нелегальних мігрантів через державний кордон та торгівлею людьми, у тому числі щодо методів боротьби 3 організованими злочинними групами, що здійснюють незаконне переправлення нелегальних мігрантів через державний кордон та торгівлю людьми, а також захисту жертв таких злочинів;(в) запровадженні всеохоплюючого діалогу 3 питань притулку, зокрема стосовно практичних аспектів реалізації Конвенції ООН про статус біженців 1951 року, Протоколу щодо статусу біженців 1967 року та інших відповідних міжнародних документів, а також шляхом забезпечення поваги принципу "невислання"; (г) правилах щодо доступу, забезпечення прав та статусу осіб, яким надано доступ, гідному поводженні та інтеграції іноземців, які проживають на законних підставах; (г) подальшому розвитку оперативних заходів у сфері управління кордонами.

Угода про асоціацію передбачає співробітництво з метою попередження та запобігання актам тероризму згідно з міжнародним правом щодо захисту прав людини, біженців та гуманітарним правом, а також відповідними нормативними та підзаконними актами України та країн ЄС [8].

Угода про асоціацію між Україною i Європейським Союзом спрямована на сприяння поступовій гармонізації зовнішньої політики, політики безпеки й оборони України з відповідними політиками ЄС на двосторонньому, регіональному i багатосторонньому рівнях. До них 
належать питання Спільної зовнішньої і безпекової політики (CFSP) та Спільної політики з безпеки й оборони (CSDP). CFSP охоплює цілі й питання, що становлять стратегічний інтерес для $\mathrm{EC}$, спільні дії і позиції, схвалені Свропейським Союзом, а також процедури реалізації цих дій i позицій. У 2014 році ступінь узгодженості політики України з положеннями CFSP сягнув 73\%.CSDP охоплює широке коло завдань, включаючи гуманітарні завдання, запобігання конфліктам, операції із роззброєння i миротворчі операції, розгортання бойових підрозділів для врегулювання криз, а також для стабілізації ситуації після конфлікту.

Документ передбачає співпрацю між Україною та ЄС у сфері запобігання конфліктам і врегулювання криз в інших країнах світу. Після анексії Криму Україна залишила свої підрозділи в розпорядженні штабквартири EUNAVFOR Atlanta, але вивела свій фрегат «Гетьман Сагайдачний». Україна може співпрацювати з органами й установами CSDP, включаючи Європейське оборонне агентство, Супутниковий центр Свропейського Союзу, а також Свропейський коледж безпеки й оборони. Україна і ЄС також домовилися сприяти запобіганню поширенню зброї масового знищення, боротися $з$ тероризмом і незаконною торгівлею зброєю, а також співпрацювати у сфері контролю над озброєнням, експортом зброї і торгівлею зброєю, включаючи стрілецьку зброю [9].

Сторони Угоди зобов'язалися співпрацювати 3 метою мирного врегулювання регіональних конфліктів і підтверджують свою відданість дотриманню міжнародних принципів суверенітету, територіальної цілісності й непорушності кордонів. Анексія Криму Росією та «гібридна» війна, яку вона веде на Донбасі, у 2014 році різко змінили напрям співробітництва у сфері зовнішньої і безпекової політики. До прикладів такого співробітництва можна віднести дипломатичні заходи в так званому «нормандському форматі» (Німеччина, Франція, Україна і Росія), які завершилися ухваленням Берлінської декларації (липень 2014 р.), підписанням Мінського протоколу й меморандуму (вересень 2014 р.), а також декларації «Мінськ 2» (лютий 2015 р.). ЄС підтримує ці зусилля і продовжує чинити тиск на Росію шляхом застосування персональних i галузевих санкцій. Він підтримує роль, відведену Організації з безпеки та співробітництва в Європі (ОБСС) щодо здійснення нагляду за виконанням Мінських протоколів за допомогою Спеціальної моніторингової місії ОБСЄ і Місії спостерігачів ОБСЄ, до завдання яких входить здійснення моніторингу кордонів i дотримання домовленості про припинення вогню. Паралельно 3 цим було проведено низку тристоронніх переговорів між Європейською Комісією, Росією та Україною на підтримку комплексу заходів із виконання Мінських угод[10].

Оскільки Росія офіційно спростовує свою участь у військовому конфлікті на Донбасі, а Захід неспроможний примусити їі це визнати, Україна не змогла досягти хоча б будь-якої деескалації за допомогою 
двосторонніх переговорів. Мінський мирний процес розпочався за підтримки ЄC. Активні дипломатичні зусилля 3 боку $\mathrm{CC} \mathrm{i} \mathrm{його} \mathrm{держав-членів} \mathrm{у}$ поєднанні із санкціями, введеними щодо російських громадян і компаній, дещо сприяли послабленню військових дій, що, у принципі, малоб забезпечити врегулювання конфлікту мирним шляхом. Україна приєдналася до деяких рішень $Є С$, запровадивши низку санкцій, включаючи заборону на в’їзд і заморожування активів фізичних та юридичних осіб, які своїми діями зазіхають на територіальну цілісність України. Україна також ввела ембарго на імпорт та експорт певних товарів з/до Росії, включаючи зброю і супутні матеріали, а також заборонила польоти російських авіакомпаній до країни. Україна також виступає за посилення міжнародних санкцій проти Росії. У грудні 2015 року парламент України закликав парламенти інших держав розширити і посилити санкції проти Росії за організацію терористичних актів в Україні. Посилаючись на Угоду про асоціацію, Україна має намір посилити зближення своєї зовнішньої політики з CFSP/CDSP40.

Утім, це не означає, що Україна готова беззастережно прийняти позицію ЄС. Деякі підходи, запропоновані $\mathrm{CC}$, неприйнятні для України. Наприклад, зміни до Конституції, що передбачають запровадження особливого режиму місцевого самоврядування на Донбасі, були фактично заблоковані в парламенті через побоювання, що вони можуть підірвати суверенітет України. Відповідно до Плану заходів з імплементації Угоди про асоціацію Україна має намір висувати пропозиції щодо формування спільної з СС позиції на основі моніторингу ситуації у сфері безпеки в Східній Європі [11].

У 2017 р. було запроваджено створену за гроші СС систему моніторингу «Пульс Угоди», який відображає поточний прогрес виконання заходів у межах кожного року та загальний прогрес виконання, починаючи 3 тимчасового застосування окремих положень Угоди у 2014 р.20 листопада 2019 р. Кабінет міністрів відкрив публічний доступ до "Пульсу угоди". За уряду В.Гройсмана іiі відкриття блокував особисто прем'єр, бо вона виявилася "занадто об'єктивною" і демонструвала не лише здобутки, а й проблеми уряду. Розміщена на сайті pulse.eu-ua.org, система оновлюється щоквартально і відображає відсоток виконання зобов'язань за кожним із напрямів УА, частку прострочених зобов'язань, а також ті, чия реалізація перебуває у зоні ризику. Наразі найбільший прогрес у адаптації законодавства ЄC фіксується якраз у напрямі "Національний діалог, національна безпека та оборона": тут Україна виконала $84 \%$ своїх зобов'язань. Втім, ключові реформи були проведені ще у 2015 році [12].

Прогрес виконання задач по Другому розділу “Політичний діалог та реформи, політична асоціація, співробітництво та конвергенція у сфері зовнішньої та безпекової політики за 2015 рік становив 90\%, за 2016 рік 90\%, за 2017 рік - 35\%, за 2018 рік - 75\%. [13]. Зокрема, прогрес виконання 
задач на 2015 рік включав в себе відновлення роботи 3 проведення конституційної реформи (100\%). В 2015 р. була затверджена нова редакція Стратегії національної безпеки України з урахуванням курсу на європейську інтеграцію (100\%), узгоджені документи оборонного планування 3 євроінтеграційним пріоритетом зовнішньої політики України (100\%), започатковано співробітництво 3 Європейським оборонним агентством (100\%),створено спільну українсько-литовсько-польську військовубригаду (100\%).У червні 2015 року розпочато переговори щодо укладання між Міністерством оборони України та Європейським оборонним агентством угоди, спрямованої на розвиток військово-технічного співробітництва. Крім того, у вересні 2015 року Рада національної безпеки й оборони прийняла нову Воєнну доктрину України, яка відображає ціль держави щодо інтеграції в $\mathrm{CC}$.

Об’єм виконання задач на 2016 рік становив 90\%. Забезпечено участь підрозділів 3СУ у складі Бойової тактичної групи СС, сформованої країнами Вишеградської четвірки (100\%). Проте обсяг виконання завдань на 2017 рік зменшився до 35\%. Не було затверджено концепцію реформи Служби безпеки України (0\%), не повністю удосконалено систему державного експортного контролю (50\%). Прогрес у виконанні завдань на 2018 рік становив 75\%. У червні 2018 року за підтримки європейських експертів було розроблено і прийнято Закон України « Про національну безпеку » (від 21.06.2018№2469-VIII), який передбачав реформування всього сектору безпеки. У рамках проєктів Свропейського оборонного агентства українські експерти залучені до роботи експертних груп "Матеріальна стандартизація", “Єдине європейське небо" та “Европейський авіатранспортний флот". За 2019 рік завдання виконані на 100\%, а саме - комплексне вдосконалення законодавства 3 питань національної безпеки і оборони України (100\%). У навчальних закладах Міноборони введено окрему дисципліну “Європейська безпека” (окремо від євроатлантичної), яка має зосередитись на вивченні усіх складових СПБО (основи СПБО, миротворча діяльність $\mathrm{CC}$, PESCO, EDA, невійськові виміри безпеки, бойові тактичні групи $\mathrm{CC}$, безпекова співпраця EC - НАТО тощо). У контексті регіональної безпекової співпраці запроваджено регулярні зустрічі начальників генеральних штабів України, країн Вишеградської групи і країн Балтії 3 метою обміну досвідом та передовими практиками. Вжито заходи щодо відновлення участі України в рамках Бойової тактичної групи СС, сформованої країнами Вишеградської четвірки під час наступних її бойових чергувань після 2019 року. Україна та ЄC досягли політичного консенсусу щодо приєднання до низки ініціатив Свропейського Союзу щодо протидії кіберзагрозам із залученням Агенції 3 питань мережевої та інформаційної безпеки Свропейського Союзу, Свропейського центру досліджень та компетенцій з кібербезпеки. 
Відповідальними за визначений безпековий напрям УА визначено Міністерство закордонних справ України, Комітет Верховної Ради України 3 питань національної безпеки, оборони та розвідки, Комітет ВРУз питань зовнішньої політики та міжпарламентського співробітництва. Отже, загальний прогрес за період 01.11.2014-31.10.2019 становить 84\%. В цілому ж, відповідно до Навігатора Угоди, станом на24 листопада 2019 р. загальна кількість зобов'язань сягала 2071, 3 них виконано - 119, невиконано - 405, а по 1543 розгляд не розпочато [14].

Зберігаються високі темпи приєднання України до заяв та декларацій від імені ЄС, що свідчить про спільність поглядів та підходів у питаннях належного реагування на регіональні та глобальні виклики. Протягом 2018 року Україна приєдналася до 492 з 588 заяв та декларацій ЄС.

Виконання Угоди про асоціацію $є$ предметом постійного діалогу органів влади 3 громадянським суспільством. 3 моменту підписання Угоди про асоціацію та початком діяльності Української сторони Платформи громадянського суспільства громадськість стала невід'ємною частиною процесу прийняття євроінтеграційних рішень в уряді. Саме громадська експертна оцінка сприяє об'єктивній оцінці прогресу виконання євроінтеграційних реформ.Постійне розширення санкційної політики $Є С$ по відношенню до РФ відповідно до Рішення Ради ЄС 2019/416 та імплементаційного регламенту 2019/409 від 14 березня 2019 р., а також рішення Управління 3 контролю за іноземними активами Міністерства фінансів США від 15.03.2019 - до нового пакету санкцій увійшли 848 фізичних та 294 юридичі особи. Потребує продовження діалог щодо посилення режиму санкцій $Є С$ проти РФ, у тому числі за рахунок “азовського пакету” [15].

Отже, протягом 2014-2019 рр. відбувається процес імплементації Угоди про асоціацію між Україною та ЄС. Найбільш успішно втілення в життя зазнає розділ «Політичний діалог та реформи, політична асоціація, співробітництво та конвергенція у сфері зовнішньої та безпекової політики» (Україна виконала 84\% своїх зобов'язань). Анексія Криму Росією та її агресія на Донбасі різко змінили напрям співробітництва у сфері зовнішньої і безпекової політики. СС підтримує ці зусилля і продовжує чинити тиск на Росію шляхом застосування персональних і галузевих санкцій. Водночас потребує продовження діалог щодо посилення режиму санкцій $Є С$ проти РФ і запровадження нових форматів співробітництва з метою обміну досвідом та передовими практиками.

\section{Список використаних джерел}

1. Артьомов І.В. На шляху до безвізового режиму СС і України: моніторинг проблеми//Геополітика України: історія і сучасність: зб.наук.пр. Вип.8 /Матеріали міжнародної науково-практичної конференції «Шляхи 
підвищення ефективності транскордонного співробітництва на новому Східному кордоні Свропейського Союзу», м. Стара Лесна, Словацька Республіка, 1819 вересня 2012 р. Ужгород: ЗакДУ, 2012. С. 116-122.

2. Імплементація Угоди про асоціацію між Україною та $\mathrm{CC}$ : економічні виклики та нові можливості : наукова доповідь / за ред. акад. НАН України В.М.Гейця та чл.-кор. НААН України Т.О.Осташко; НАН України, ДУ "Ін-т екон. та прогнозув. НАН України". К., 2016. 184 с.

3. Дем'янчук О. П., Леденьова А. В. Угода про асоціацію між Україною та СС крізь призму моделі «дворівневої гри»...//8 Наукові записки. НаУКМА, 2016. Том 186. Політичні науки.

4. Левченко О.В. Уточнення понятійного апарату 3 питань оцінювання рівня воєнної загрози національній безпеці України / О.В. Левченко, В. В. Троцько, І. С. Василенко // Наука і оборона. 2014. №2. C. $16-19$.

5. Муравйов В.I. Правові засади асоціації України з Свропейським Союзом/ Актуальні проблеми міжнародних відносин: збірник наукових праць. Випуск 115. Частина II, 2013 URL: http://journals.iir.kiev.ua /index.php/apmv/article/viewFile/1944/1709

6. Носова О. Угода про асоціацію України та Європейського Союзу: економічні наслідки // Агора. 2015. Вип. 15. С. 86-91.

7. Пошедін О. I. Воєнна безпека України в контексті співробітництва з Європейським Союзом // Вісник Національної академії державного управління при Президентові України. 2014. №3. С. 53-60.

8. Угода про асоціацію між Україною, 3 однієї сторони, та Європейським Союзом, Європейським співтовариством з атомної енергії i їхніми державами-членами, 3 іншої сторони: міжнародний документ від 27.06.2014. Ратифікована 16.09.2014 p. URL: http://zakon5.rada. gov.ua/laws/show/984_011. - Назва з екрана.

9. Поглиблення відносин між ЄС та Україною: Що? Чому і як? Київ, 2016. - С. 31.

10. Outcome of the Trilateral Talks on the Implementation of the EUUkraine Association Agreement/Deep and Comprehensive Free Trade Area. September 7, 2015. URL: http://europa.eu/rapid/press-release_STATEMENT-155603 en.htm.

11. Про звернення до парламентів іноземних держав, Свропейського Парламенту i парламентських асамблей міжнародних організацій щодо продовження та посилення санкцій проти Російської Федерації за організацію терористичних актів в Україні. URL: https://zakon.rada.gov.ua /laws/show/892-19.

12. Панченко Ю., Сидоренко С. Успіхи та провали євроінтеграції: що дасть відкриття системи "Пульс угоди". URL: https://www.eurointegration. com.ua/articles/2019/11/20/7103281/ 
13. Пульс Угоди. URL: http://pulse.eu-ua.org/.

14. Навігатор Угоди. URL: http://navigator.eurointegration.com.ua/tasks

15. Свропейська та євроатлантична інтеграція України. Transition book-2019. - Київ, 2019. - С. 29.

\section{REFERENCES}

1. Artiomov I.V. (2012) Na shlyakhu do bezvizovoho rezhymu ES i Ukrayiny: monitorynh problemy [Towards a Visa-Free Regime of the EU and Ukraine: Monitoring the Problem] Heopolityka Ukrayiny: istoriya i suchasnist' [Geopolitics of Ukraine: History and Modernity: Collected Research Papers. Issue 8 / Proceedings of the International Scientific and Practical Conference "Ways to Improve the Effectiveness of Cross-Border Cooperation at the New Eastern Border of the European Union", Stara Lesna, Slovak Republic, September 18-19, 2012 Uzhgorod: ZakU. - Pp. 116 -122. [In Ukrainian].

2. Demianchuk O. P., Ledeniova A. V. (2016) Uhoda pro asotsiatsiiu mizh Ukrainoiu ta ES kriz' pryzmu modeli «dvorivnevoyi hry» [Agreement between Ukraine and the EU through the Prism of the Two-Level Game Model]. Naukovizapysky. [Scientific notes] NaUKMA, vol. 186. Political research. [In Ukrainian].

3. Implementatsiya Uhod y proasotsiatsiyu mizh Ukrayinoyu ta ES: ekonomichni vyklyky ta novi mozhlyvosti: naukova dopovid' (2016) [Implementation of the EU-Ukraine Association Agreement: Economic Challenges and New Opportunities: Scientific Report] / ed. by V.M. Heytsand T.O.Ostashko; NAS of Ukraine, State Institution "Institute of Economics and Forecasting NAS of Ukraine". Kyiv. - 184 p. [In Ukrainian].

4. Levchenko O. V., Trots'ko V. V., Vasylenko I. C. (2014) Utochnennya ponyatiynoho aparatu $\mathrm{z}$ pytan' otsinyuvannya rivnya voyennoyi zahrozy natsional'niy bezpetsi Ukrayiny [Clarification of the Conceptual Apparatus for Assessing the Level of Military Threat to the National Security of Ukraine]. Naukaioborona [Science and Defense] No 2, p. 16-19. [In Ukrainian].

5. Muravyov V.I. (2013)Pravovi zasady asotsiatsiy i Ukrayiny $z$ Yevropeys'kym Soyuzom [Legal Basis of the Association of Ukraine with the European Union]Aktual'ni problem mizhnarodnykh vidnosyn: Zbirnyk naukovykh prats [Current Issues in International Relations: Collection of Scientific Papers]. Issue 115. Part II. Retrieved from: http://journals.iir.kiev.ua/index.php/apmv/ article/viewFile/1944/1709Accessed 16.10.2019 [In Ukrainian].

6. Navihator Uhody [Agreement Navigator] (2019). - Retrieved from: http://navigator.eurointegration.com.ua/tasks. Accessed 20.10.2019[In Ukrainian].

7. Nosova O. (2015) Uhoda pro asotsiatsiyu Ukrayiny ta Yevropeys'koho Soyuzu: ekonomichni naslidky[Association Agreement between Ukraine and the European Union: Economic Implications] Ahora.-Issue 15. P.86-91.[In Ukrainian]. 
8. Outcome of the Trilateral Talks on the Implementation of the EUUkraine Association Agreement/Deep and Comprehensive Free Trade Area (September 7, 2015). - Retrievedfrom: http:/europa.eu/rapid/pressrelease_STATEMENT-15-5603_en.htm. [In English].

9. Panchenko Yu., Sydorenko S. (2019) Uspikhy ta provably yevrointehratsiyi: shchodast' vidkryttya systemy "Pul's uhody". [Successes and failures of European integration: what will opening of the "Agreement Pulse" system result in]. - Retrieved from: https://www.eurointegration.com.ua/ articles/2019/11/20/7103281/. Accessed 01.11.2019 [In Ukrainian].

10. Pohlyblennya vidnosyn mizh ES ta Ukrayinoyu: Shcho? Chomui yak?(2016) [Deepening EU-Ukraine relations: What? Why and how?] Kyiv, p.31.[In Ukrainian].

11. Poshedin O. I. (2014) Voyenna bezpeka Ukrayiny v konteksti spivrobitnytstva z Yevropeys'kym Soyuzom[Military Security of Ukraine in the Context of Cooperation with the European Union] Visnyk Natsional'noyi akademiyi derzhavnoho upravlinnya pry Prezydentovi Ukrayiny - Bulletinof the National Academy of Public Administration of the President of Ukraine. No 3,p. 53-60.[In Ukrainian].

12. Pro zvernennya do parlamentiv inozemnykh derzhav, Yevropeys'koho Parlamentuiparlament:s'kykh asambley mizhnarodnykh orhanizatsiy shchodo prodovzhennya ta posylennya sanktsiy proty Rosiys'koyi Federatsiyi za orhanizatsiyu terorystychnykh aktiv $v$ Ukrayini ["On Appeal to the Parliaments of Foreign States, the European Parliament and the Parliamentary Assemblies of International Organizations to Continue and Enhance Sanctions against the Russian Federation for the Organization of Terrorist Acts in Ukraine"] (2015). Retrievedfrom: https://zakon.rada.gov.ua/laws/show/892-19Accessed 13.11.2019. [In Ukrainian].

13. Pul'sUhody [the "Agreement Pulse"] (2019).Retrievedfrom: http://pulse.eu-ua.org/Accessed 11.11.2019[In Ukrainian].

14. Uhoda pro asotsiatsiyu mizh Ukrayinoyu, $\mathrm{z}$ odniyeyi storony, ta Yevropeys'kym Soyuzom, Yevropeys'kym spivtovarystvom $\mathrm{z}$ atomnoyi enerhiyi i yikhnimy derzhavamy-chlenamy, $\mathrm{z}$ inshoy istorony. (2014) [Association Agreement between Ukraine, of the one part, and the European Union, the European Atomic Energy Community, and their Member States, of the other part.] International document dated 27.06.2014. Ratified 09/16/2014. Retrievedfrom: http://zakon5.rada.gov.ua/ laws/show/984_011 Accessed 11.10.2019. [In Ukrainian].

15. Yevropeys'ka ta yevroatlantychna intehratsiya Ukrayiny. [European and Euro-Atlantic integration of Ukraine.] (2019) Transition book-2019. - Kyiv, p. 29. 